\title{
Mannheimia caviae sp. nov., isolated from epidemic conjunctivitis and otitis media in guinea pigs
}

\begin{abstract}
Correspondence
H. Christensen

hech@life.ku.dk
\end{abstract}

\author{
H. Christensen, A. M. Bojesen and M. Bisgaard \\ Department of Veterinary Disease Biology, Faculty of Life Sciences, University of Copenhagen, \\ 4 Stigbøjlen, DK-1870 Frederiksberg C, Denmark
}

Strains $\mathrm{T} 138021-75^{\top}, \mathrm{Pg} 19$ and $\mathrm{Pg} 20$ (taxon 25 of Bisgaard) were isolated from guinea pigs and characterized. Strains T138021-75 ${ }^{\top}$ and $\mathrm{Pg} 20$ showed identical $16 \mathrm{~S}$ rRNA gene sequences and were distantly related to the published strain P224 with the highest 16S rRNA similarity of 98.6\%. These two strains showed $97.8 \%$ sequence similarity with the type strain and other strains of Mannheimia glucosida and $97.3 \%$ similarity with the type strain of Mannheimia varigena, but $<97 \%$ similarity with all other type strains of the genus Mannheimia, including Mannheimia haemolytica (96.9\%). Phylogenetic analysis of rpoB gene sequences showed that strain P224 had a distant position ( $89.9 \%$ gene sequence similarity) compared with the three other strains (T138021-75 ${ }^{\top}, \mathrm{Pg} 20$ and $\left.\mathrm{Pg} 19\right)$, which had identical gene sequences. These three novel strains also shared identical $r e c N$ gene sequences. Phylogenetic analysis of the recN gene sequences showed a close relationship between the three novel strains and strain P224. The DNA-DNA reassociation value between strain $\mathrm{T} 138021-75^{\top}$ and $\mathrm{P} 224$ was $81.6 \%$ and $40.3 \%$ between strain T138021-75 ${ }^{\top}$ and the type strain of M. glucosida. Based on the DNA-DNA reassociation data, strain $\mathrm{T} 138021-75^{\top}$ belonged to a separate species that was closely related to strain P224. Strain P224 differed from strains T138021-75 ${ }^{\top}, \mathrm{Pg} 20$ and Pg19 in the following phenotypic characteristics: activity of ornithine carboxylase, hydrolysis of glycosides, and acid formation from maltose, dextrin, melibiose and raffinose, as well as reactions for $\alpha$-galactosidase and $\beta$-xylosidase. Whole genome similarity calculations based on $\operatorname{rec} N$ gene sequences showed that strains T138021-75 ${ }^{\top}$ and P224 were related at the species level (0.932), whereas 16S rRNA and partial $r p o B$ gene sequence comparisons showed a more divergent position of strain P224 compared with the novel strains, including a different host of isolation. The results showed that the three strains of taxon 25 represent a novel species for which the name Mannheimia caviae sp. nov. is proposed. The type strain, T138021-75 ${ }^{\top}$ (=CCUG $59995^{\top}=$ DSM $23207^{\top}$ ) was isolated from purulent conjunctivitis in guinea pigs. Previous publications have documented both ubiquinones and demethylmenaquinone to be present in the type strain. The $\mathrm{G}+\mathrm{C}$ content of the DNA of the type strain has been found to be $41.4 \mathrm{~mol} \%\left(T_{\mathrm{m}}\right)$.
Although they have been known for decades, the taxonomy of most taxa of the family Pasteurellaceae that are associated with laboratory rodents has remained unsolved (Bisgaard, 1993; Christensen \& Bisgaard, 2008). An unclassified Pasteurella-like organism was reported to be associated with subdermal abscesses in guinea pigs by Stewart \& Letscher (1976). Very similar isolates were subsequently reported as the 'SP' group by Frederiksen (1981). Several phenotypically identical Pasteurella-like organisms were also reported by Mannheim et al. (1978) from an outbreak of epidemic

The GenBank/EMBL/DDBJ accession numbers for the partial $16 \mathrm{~S}$ rRNA, rpoB and recN gene sequences of strain $T 138021-75^{\top}$ are HM439607, HM439605 and HM439606, respectively.

Supplementary figures and a supplementary table are available with the online version of this paper. conjunctivitis in a large colony of guinea pigs. Although widely distributed among mammals and birds, infections due to Pasteurella multocida do not appear to be common in guinea pigs (Ganaway, 1976). Isolates belonging to $P$. multocida biovar 1 were, however, reported by Frederiksen (1973). Mráz et al. (1979) demonstrated that [Pasteurella] ureae was present in $47.5 \%$ of guinea pigs investigated. This species was later reclassified and named as Actinobacillus ureae (Mutters et al., 1986). Attempts to clarify the natural occurrence of members of the family Pasteurellaceae in two colonies of conventional and well managed guinea pigs by Bisgaard et al. (1983), demonstrated at least four novel taxa (originally termed Bisgaard Taxa 5 to 8), all of which have subsequently been demonstrated to represent genuine members of the family Pasteurellaceae (Christensen \& Bisgaard, 2008). 
Organisms tentatively designated as members of the SPgroup have been reported from guinea pigs and from human blood and faeces (Frederiksen, 1981). Guinea pig isolates classified as belonging to the SP-group or taxon 6, respectively, give clearly different results in both biochemical (Boot \& Bisgaard, 1995) and serological tests (Boot et al., 1995). Based upon 41 phenotypical characteristics, Kunstýr \& Hartmann (1983) investigated the prevalence of members of the family Pasteurellaceae in laboratory animals, including guinea pigs. Unfortunately, information on the hosts associated with the different taxa demonstrated was not provided. Although a final classification was not given, Boot et al. (1983) concluded that members of the Pasteurella-Actinobacillus group must be considered as potentially pathogenic for guinea pigs. Subsequently, Boot \& Walvoort (1986) concluded that otitis media, from which members of the family Pasteurellaceae also could be demonstrated, must be considered a major disease problem in guinea pigs. The importance of including reference or type strains for comparison and extended phenotypic characterization to avoid misclassification was demonstrated by Boot \& Bisgaard (1995). Isolates from guinea pigs previously reported as Pasteurella gallinarum (later reclassified as Avibacterium gallinarum) were reclassified as members of the SP-group, taxon 6 or taxon 25. Two isolates, Pg19 and Pg20, recovered from guinea pigs suffering from otitis media and classified as taxon 25, demonstrated phenotypical characteristics that were clearly different from the other species of the family Pasteurellaceae that were also studied (Boot \& Bisgaard, 1995). These two isolates have subsequently been shown to share the phenotypical characteristics of a group of organisms represented by strain T138021-75 ${ }^{\mathrm{T}}$ as reported by Mannheim et al. (1978) (M. Bisgaard, unpublished data). The aims of the present study were to classify and name organisms tentatively named taxon 25 in order to improve the diagnosis of these organisms, gain a better understanding of their epidemiology and enable the selection of suitable strains for virulence studies.

The three clinical isolates, strains T138021-75 ${ }^{\mathrm{T}}, \mathrm{Pg} 19$ and Pg20, were characterized. Strain P224 (see Supplementary Table S1 available in IJSEM Online), previously identified as being a possible species of the genus Mannheimia (Kuhnert et al., 2007), was also included for comparison. The type strains of the five species of the genus Mannheimia (Angen et al., 1999) and the type strain of P. multocida were also included for comparison based on their published DNA sequences. Phenotypic characterization was carried out as reported previously (Bisgaard et al., 1991; Christensen et al., 2007) which enabled comparisons to be made with previous characteristics determined in our laboratory. For phylogenetic comparisons of $16 \mathrm{~S}$ rRNA and $r p o B$ gene sequences, additional sequences of Mannheimia haemolytica and Mannheimia glucosida were included based on the highest score with a BLAST search (Altschul et al., 1997) in GenBank (Benson et al., 2006).

The partial $r p o B$ gene sequences of the three isolates investigated (Supplementary Table S1) were determined according to Mollet et al. (1997) covering the region 509680 (positions according to Escherichia coli numbering) of the deduced protein sequence as reported previously (Angen et al., 2003; Korczak et al., 2004). Sequencing of the $16 \mathrm{~S}$ rRNA gene of two strains (Supplementary Table S1) was performed according to previous reports (Christensen et al., 2002a; Angen et al., 2003). In addition, $r e c N$ gene sequences were used as a representative target for determining wholegenome sequence similarity as described by Kuhnert \& Korczak (2006), with 1340 bp of the gene being sequenced. Primers recN-L and recN-R were used for PCR and for sequencing the additional primers recNR + recNMannF (5'-AGCAATCTCGCTTGCTCGTA) and recNL + recNTx 25R1 (5'-AAAGCTCGGTCAGTTCTTCG) were included. Sequencing was performed by Macrogen (Korea). For recN gene sequences, whole genome similarity values were calculated according to Zeigler (2003). Pairwise comparisons for similarity were performed by the program WATER included in EMBOss (Rice et al., 2000). Multiple alignment was performed with CLUSTAL_X (Thompson et al., 1997). Maximum-likelihood analysis including bootstrap analysis was performed by fastDNAml (Olsen et al. 1994; Felsenstein, 1995) on a Linux compatible server. The analysis was run with transition/transversion ratios of 1.3, 2.4 and 1.8 for the $16 \mathrm{~S}$ rRNA, rpoB and $\mathrm{recN}$ multiple gene sequence alignments, respectively.

Phylogenetic analysis of nearly full-length $16 \mathrm{~S}$ rRNA gene sequences, partial $r p o B$ gene sequences and nearly fulllength $\operatorname{recN}$ gene sequences are shown in Fig. 1, Supplementary Fig. S1 and Supplementary Fig. S2, respectively. Strains T138021-75 ${ }^{\mathrm{T}}$ and Pg20 showed identical $16 \mathrm{~S}$ rRNA gene sequences and were distantly related to other species of the genus Mannheimia including strain P224 (98.6\%) (Fig. 1). The highest 16S rRNA gene sequence similarity $(97.8 \%)$ to other taxa was to the type strain and other strains of M. glucosida (P733, P933 and H62). The type strain of Mannheimia varigena showed $97.3 \% 16 \mathrm{~S}$ rRNA gene sequence similarity. All other type strains of the genus Mannheimia, including the type strain of M. haemolytica (96.9\%), showed less than $97 \%$ similarity

Phylogenetic analysis of the $r p o B$ gene sequences showed the distant position of strain P224 compared with the other three strains (T138021-75 $\left.{ }^{\mathrm{T}}, \mathrm{Pg} 20, \mathrm{Pg} 19\right)$ that shared identical sequences (Supplementary Fig. S1). The closest related strains included the type strains of $M$. varigena and M. haemolytica (biovar 8), both showing $93.9 \%$ similarity, while strain P224 only demonstrated $89.9 \%$ sequence similarity. The highest $r p o B$ gene sequence similarity for strain P224 was 95.1\%, which was observed with the type strains of M. haemolytica and M. glucosida.

The three strains of taxon $25\left(\mathrm{~T} 138021-75^{\mathrm{T}}, \mathrm{Pg} 20\right.$ and Pg19) also shared identical $r e c N$ gene sequences. However, here the phylogenetic analysis showed a close relationship with strain P224 (Supplementary Fig. S2). The close relatedness of strain P224 to the three strains of taxon 25 


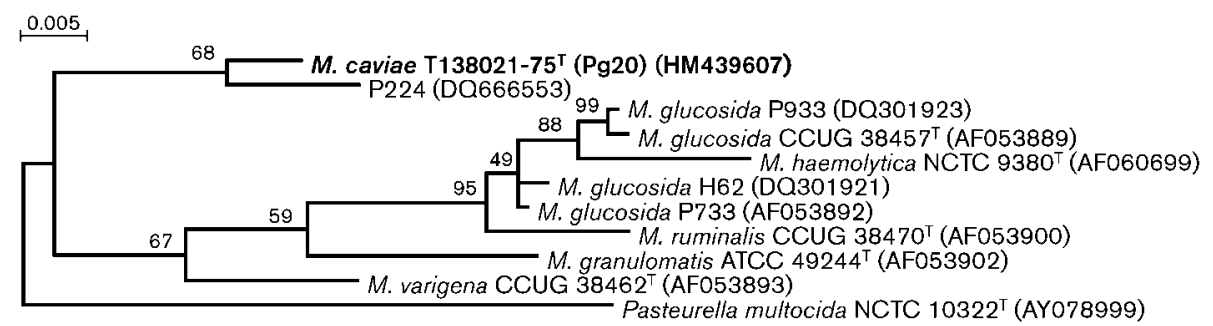

Fig. 1. Phylogenetic relationships between the novel isolates investigated and recognized members of the family Pasteurellaceae based on maximum-likelihood analysis of near full-length 16S rRNA gene sequences. Support for monophyletic groups by bootstrap-analysis is indicated as numbers out of 100. Strain numbers are followed by DDBJ/ EMBL/GenBank accession numbers. Strain numbers in bold represent strains that were sequenced in the present investigation. Strains in parentheses share sequences with the preceding strain the same branch. Bar, sequence variation considering the models for nucleotide substitution and tree-shape used in the maximum-likelihood analysis.

in the $16 \mathrm{~S}$ rRNA and $\operatorname{recN}$ gene sequence phylogenies, but not in the $r p o B$ gene sequence phylogeny, may point to the horizontal gene transfer of $r p o B$ from another source other than the last common ancestor of P224 and strains T138021-75 ${ }^{\mathrm{T}}$, Pg19 and Pg20. However, within the family Pasteurellaceae, the rpoB gene has often been used to infer organism phylogeny and has not previously been suspected as having been transferred between taxa.

A threshold value of $97 \%$ 16S rRNA gene sequence similarity resulting in DNA-DNA reassociation values $<70 \%$ has been suggested as the threshold for species separation from a taxonomically conservative point of view (Tindall et al., 2010). For this reason, DNA-DNA hybridizations were performed between strains T138021$75^{\mathrm{T}}$ and P224 and between strains $\mathrm{T} 138021-75^{\mathrm{T}}$ and $M$. glucosida DSM $19638^{\mathrm{T}}$ by the spectrometric method by the Deutsche Sammlung von Mikroorganismen und Zellkulturen (DSMZ; Braunschweig). Cells were disrupted by using a French pressure cell (Thermo Spectronic) and the DNA in the crude lysate was purified by chromatography on hydroxyapatite as described by Cashion et al. (1977). DNA-DNA hybridization was carried out as described by De Ley et al. (1970) under consideration of the modifications described by Huß et al. (1983) using a Cary 100 Bio UV/VIS spectrophotometer equipped with a Peltierthermostatted $6 \times 6$ multicell charger and a temperature controller with in situ temperature probe (Varian). Measurements were performed in $2 \times \mathrm{SSC}$ at $66{ }^{\circ} \mathrm{C}$. DNA reassociation values between strains $\mathrm{T} 138021-75^{\mathrm{T}}$ and $\mathrm{P} 224$ were 82.6 and $80.5 \%$ (mean $81.6 \%$ ). DNA relatedness values between strain T138021-75 ${ }^{\mathrm{T}}$ and M. glucosida DSM $19638^{\mathrm{T}}$ were $41.8 \%$ and $38.7 \%$ (mean $40.3 \%$ ). Based on the DNA-DNA reassociation data, strain T138021-75 belongs to a separate species to M. glucosida when the recommended threshold value of $70 \%$ of DNA-DNA reassociation between species is applied (Wayne et al., 1987). Species of the family Pasteurellaceae have mainly been defined on the basis of DNA-DNA reassociation values of $80-85 \%$ as measured by the spectrophotometric method (Mutters et al., 1989; Christensen et al., 2002b,
2005). This places strain P224 at the borderline compared with strain $\mathrm{T} 138021-75^{\mathrm{T}}$.

All three novel strains (T138021-75 ${ }^{\mathrm{T}}, \mathrm{Pg} 19$ and Pg20) tested positive for catalase and oxidase activities and they were fermentative in Hugh and Leifson medium with (+)-D-glucose. The strains stained Gram-negative and were non-motile pleomorphic rods when observed at 22 and $37^{\circ} \mathrm{C}$. Common characteristics are further listed in the species description. Different reactions between the strains were observed for acid production from $(-)$-D-arabinose (strain Pg20 late positive), (-)-D-sorbitol (strains Pg19 and Pg20 positive), (-)-L-fucose (strains Pg19 and Pg20 late positive) and $\alpha$-fucosidase (o-nitrophenyl $\alpha$-Lfucopyranoside; ONPF) (strains Pg19 and Pg20 negative). The phenotypic characteristics obtained were in accordance with those previously reported for members of the genus Mannheimia (Angen et al., 1999). Characteristics that separated the guinea pig isolates from other species of the genus Mannheimia are presented in Table 1. The novel strains were separated from other recognized species of the genus Mannheimia on the basis of 4-9 different characteristics; the most closely related species was M. glucosida (Table 1). Differences in ornithine decarboxylase, growth on MacConkey agar, $\beta$-glucosidase, $\alpha$-galactosidase, $\beta$-xylosidase and production of acid from maltose, $(+)$-melibiose, raffinose, dextrin and glycosides separated the three novel strains from strain P224 (Kuhnert et al., 2007). Characteristics previously reported for strain T138021-75 ${ }^{\mathrm{T}}$ (Mannheim et al., 1978) were confirmed in this study.

The G+C content of DNA for strain T138021-75 ${ }^{\mathrm{T}}$ was estimated to be $41.4 \mathrm{~mol} \%\left(T_{\mathrm{m}}\right)$ (Mannheim et al., 1978), while $41.6 \mathrm{~mol} \%$ was reported for M. glucosida (Angen et al., 1999), its closest relative based upon phenotypic tests, and clearly within the variation of the genus Mannheimia (Angen et al., 1999).

The ability to produce ubiquinones in addition to demethylmenaquinones characterizes major groups of the family Pasteurellaceae, including species of the genus Mannheimia (Mannheim, 1981). Both ubiquinones and 
Table 1. Phenotypic characteristics separating Mannheimia caviae sp. nov. from recognized species of the genus Mannheimia

Taxa: 1, M. caviae (T138021-75 ${ }^{\mathrm{T}}, \operatorname{Pg} 19$ and Pg20); 2, M. haemolytica; 3, M. glucosida; 4, M. ruminalis; 5, M. granulomatis; 6, M. varigena. ,$+ \geqslant 90 \%$ positive within $1-2$ days; $(+), \geqslant 90 \%$ positive within $3-$ 14 days;,$- \leqslant 10 \%$ positive within 14 days; w, weak reaction; D, 11$89 \%$ positive within 14 days. Data for taxa 2-6 are from Angen et al. (1999). All taxa were investigated using the same methods and cultural conditions.

\begin{tabular}{|lcccccc|}
\hline Characteristic & $\mathbf{1}$ & $\mathbf{2}$ & $\mathbf{3}$ & $\mathbf{4}$ & $\mathbf{5}$ & $\mathbf{6}$ \\
\hline$\beta$-Haemolysis (bovine blood) & - & + & + & - & - & + \\
Ornithine decarboxylase & + & - & $\mathrm{D}$ & - & - & $\mathrm{D}$ \\
Acid formation from: & & & & & & \\
$(+)-$-Arabinose & + & - & $\mathrm{D}$ & - & - & + \\
$(+)$-D-Xylose & + & + & + & - & $\mathrm{D}$ & + \\
$m y$-Inositol & + )/W & $\mathrm{D}$ & $(+)$ & - & $\mathrm{D}$ & $\mathrm{D}$ \\
$(-)$-D-Sorbitol & $\mathrm{D}$ & + & + & $\mathrm{D}$ & + & - \\
$(+)-$-Rhamnose & - & - & - & - & - & $\mathrm{D}$ \\
Maltose & - & + & + & $\mathrm{D}$ & $+/(+)$ & $\mathrm{D}$ \\
$(+)-$-Melibiose & + & - & - & - & - & - \\
$\beta$-Glucosidase & + & - & + & - & + & - \\
Glycosides* & + & - & $\mathrm{D}$ & - & $\mathrm{D}$ & - \\
$\alpha$-Fucosidase & $\mathrm{D}$ & + & + & $\mathrm{D}$ & - & - \\
$\alpha$-Galactosidase & + & - & - & - & - & - \\
$\beta$-Xylosidase & + & - & $\mathrm{D}$ & - & $\mathrm{D}$ & - \\
\hline
\end{tabular}

${ }^{*}$ Glycosides: cellobiose, aesculin, amygdalin, arbutin, gentiobiose and salicin.

demethylmenaquinone were produced by strain T138021$75^{\mathrm{T}}$ according to Mannheim et al. (1978), underlining the classification of the novel strain within the family Pasteurellaceae.

Recently, Zeigler (2003) showed that a selection of three genes can be used to predict whole-genome relatedness. Based upon the same genes, $r e c N$, thdF and rpoA, Kuhnert \& Korczak (2006) validated their use in multilocus sequence analysis (MLSA) to predict the whole-genome DNA-DNA similarity for taxa of the family Pasteurellaceae. The results obtained showed that strains of the same species showed similarity values of 0.9 and higher, while species of the same genus had similarity values above 0.4 . Similarity values between 0.85 and 0.9 were considered intermediate and could indicate different species or subspecies, as observed for M. haemolytica/M. glucosida (0.88) or with the two subspecies of Actinobacillus equuli (0.87). Threshold similarity values for $\operatorname{recN}$ alone were comparable with very few discrepancies and this comparison was used in the present investigation. All three strains investigated shared the same $r e c N$ gene sequence that showed $98.2 \%$ similarity with strain P224. Only 78.3$81.3 \%$ similarity was observed for species of the genus Mannheimia, which converted to whole genome similarities of 0.932 between strains T138021-75 ${ }^{\mathrm{T}}$ and P224 and
0.46-0.62 between strain $\mathrm{T} 138021-75^{\mathrm{T}}$ and recognized species of the genus Mannheimia. Whole-genome similarity values calculated from $\mathrm{recN}$ gene sequences demonstrated values of $0.46,0.48,0.48,0.53$ and 0.63 between strain P224 and the type strains of Mannheimia granulomatis, M. glucosida, M. haemolytica, Mannheimia ruminalis and M. varigena, respectively (Kuhnert et al., 2007).

In conclusion, strains tentatively named taxon 25 were investigated using a polyphasic taxonomic approach and the results showed excellent correlation with the results obtained from extended phenotypic and phylogenetic investigations as well as with calculated whole-genome similarity values based on $r e c N$ gene sequences. The results obtained clearly showed that taxon 25 represents a novel species of the genus Mannheimia, for which the name Mannheimia caviae sp. nov. is proposed. It is important to name this taxon of the genus Mannheimia since it is of potential clinical importance. Strain P224 was closely related to M. caviae sp. nov. as the DNA-DNA relatedness value was at the threshold value of $82 \%$ and whole genome similarity calculations based on $\operatorname{recN}$ gene sequences showed species level relatedness of (0.932) with strain T138021-75 ${ }^{\mathrm{T}}$. 16S rRNA gene $(98.6 \%)$ and partial rpoB gene sequence comparisons $(89.9 \%)$ showed a more divergent position of strain P224 compared with the novel species. Strain P224 could be differentiated from M. caviae sp. nov. on the basis of phenotypic characteristics as it was ornithine carboxylase-negative and negative for the hydrolysis of glycosides. Strain P224 was positive in tests for acid formation from maltose and dextrin, but negative for melibiose and raffinose. Tests for $\alpha$-galactosidase and $\beta$ xylosidase were also negative (Kuhnert et al., 2007). Strain P224 was obtained from a rabbit, but the three strains of M. caviae sp. nov. were obtained from guinea pigs.

The differences in hosts and genotypic and phenotypic characteristics between strain P224 and strains T138021$75^{\mathrm{T}}, \operatorname{Pg} 19$ and Pg20 have parallels with M. varigena, for which two genotypical populations associated with pig and ruminants, respectively, have been previously demonstrated (Angen et al., 1999) and with M. granulomatis for which three populations have been documented associated with leporine, bovine and cervine hosts, respectively (Bojesen et al., 2007). Hopefully isolates related to strain P224 will be obtained in future studies to enable more taxonomic information to be generated in order to decide whether this strain belongs to a taxon that can be classified as a separate species, closely related to $M$. caviae sp. nov., or alternatively as a novel subspecies of $M$. caviae sp. nov.

\section{Description of Mannheimia caviae sp. nov.}

Mannheimia caviae sp. nov. (ca'vi.ae. N.L. n. Cavia generic name of the guinea pig; N.L. gen. n. caviae of Cavia, of a guinea pig).

Cells are non-motile at 22 and $37{ }^{\circ} \mathrm{C}$ and are Gramnegative-staining, coccoid or pleomorphic rods. Colonies on bovine blood agar are regular, circular and slightly 
raised with an entire margin. The surface of the colonies is smooth, shiny and opaque with a greyish tinge. Colonies have a diameter of $1.0-1.5 \mathrm{~mm}$ after $24 \mathrm{~h}$ incubation at $37^{\circ} \mathrm{C}$. $\beta$-Haemolysis is not observed on calf blood agar. CAMP negative on calf blood agar [CAMP is an abbreviation of the first initials of family names of the authors who described the test (Christie et al., 1944)]. The consistency of the colonies is unguent-like and the colonies do not adhere to the agar surface. All strains tested are positive for catalase and oxidase activities and demonstrate a fermentative reaction in Hugh and Leifson medium with $(+)$-D-glucose. Strains give a positive result in tests for porphyrin, nitrate reduction, alanine aminopeptidase, ornithine decarboxylase, phosphatase, growth on MacConkey agar, ONPG (o-nitro-phenyl-D-galactopyranoside), $\beta$-glucosidase (p-nitrophenyl $\beta$-D-glucopyranoside; NPG), $\alpha$-galactosidase, $\beta$-xylosidase and production of acid from glycerol, (+)-L-arabinose, (-)-D-ribose, (+)-D-xylose, myo-inositol, (-)-D-mannitol, (-)-D-fructose, (+)-Dgalactose, (+)-D-glucose, cellobiose, lactose, $(+)$-melibiose, sucrose, raffinose, aesculin, amygdalin, arbutin, gentiobiose and salicin. Symbiotic growth (NAD requirement) is not observed. The Simmons citrate test is negative, as well as the formation of acid from mucate, base formation from malonate, $\mathrm{H}_{2} \mathrm{~S} / \mathrm{TSI}$, growth in the presence of $\mathrm{KCN}$, methyl red test, Voges-Proskauer test at $37{ }^{\circ} \mathrm{C}$, production of gas from nitrate, urease, arginine dihydrolase, lysine decarboxylase, phenylalanine deaminase, indole, gelatinase, hydrolysis of Tween 20 and 80, formation of pigment, $\alpha$ glucosidase (p-nitrophenyl $\alpha$-D-glucopyranoside; PNPG), $\beta$ glucuronidase (p-nitrophenyl $\beta$-D-glucopyranosiduronic acid; PGUA), $\alpha$-mannosidase, production of acid from meso-erythritol, adonitol, (+)-D-arabitol, xylitol, (-)-Lxylose, dulcitol, (+)-D-fucose, (+)-D-mannose, $(+)$-Lrhamnose, $(-)$-L-sorbose, maltose, trehalose, $(+)$-melezitose, dextrin, $(+)$-D-glycogen, inulin, $(+)$-turanose, $\beta-\mathrm{N}$ $\mathrm{CH}_{3}$-glucosamide and production of gas from $(+)$-Dglucose. Variations are observed as to acid production from $(-)$-D-sorbitol and $\alpha$-fucosidase, the type strain is negative and positive, respectively, for these tests. Acid formation from (-)-D-arabinose is negative for the type strain, but strain Pg20 gives a late positive reaction. Acid formation from (-)-L-fucose is negative for the type strain, but strains Pg19 and Pg20 give a late positive result. All isolates conform to the phenotypic characteristics as described for the genus Mannheimia (Angen et al., 1999). These characteristics allow the species to be separated from other species of the genus Mannheimia by at least four characteristics. The detailed phenotypic characteristics for all three isolates are presented in this study. Both ubiquinones and demethylmenaquinone are present in the type strain according to Mannheim et al. (1978).

The type strain, T138021-75 ${ }^{\mathrm{T}} \quad\left(=\mathrm{CCUG} 59995^{\mathrm{T}}=\mathrm{DSM}\right.$ $23207^{\mathrm{T}}$ ) was obtained from purulent conjunctivitis in guinea pigs. The $\mathrm{G}+\mathrm{C}$ content of DNA of the type strain is $41.4 \mathrm{~mol} \%\left(T_{\mathrm{m}}\right)$ (Mannheim et al., 1978). Other strains are $\mathrm{Pg} 19$ and Pg20.

\section{Acknowledgements}

Excellent technical assistance was contributed by technician Pia Mortensen. We would like to express our thanks to Professor Jean P. Euzéby, Ecole Nationale Vétérinaire, Toulouse, France for help with the Latin species name.

\section{References}

Altschul, S. F., Madden, T. L., Schäffer, A. A., Zhang, J., Zhang, Z., Miller, W. \& Lipman, D. J. (1997). Gapped BLAST and PSI-BLAST: a new generation of protein database search programs. Nucleic Acids Res 25, 3389-3402.

Angen, Ø., Mutters, R., Caugant, D. A., Olsen, J. E. \& Bisgaard, M. (1999). Taxonomic relationships of the [Pasteurella] haemolytica complex as evaluated by DNA-DNA hybridizations and 16S rRNA sequencing with proposal of Mannheimia haemolytica gen. nov., comb. nov., Mannheimia granulomatis comb. nov., Mannheimia glucosida sp. nov., Mannheimia ruminalis sp. nov. and Mannheimia varigena sp. nov. Int J Syst Bacteriol 49, 67-86.

Angen, O., Ahrens, P., Kuhnert, P., Christensen, H. \& Mutters, R. (2003). Proposal of Histophilus somni gen. nov., sp. nov. for the three species incertae sedis 'Haemophilus somnus', 'Haemophilus agni' and 'Histophilus ovis'. Int J Syst Evol Microbiol 53, 1449-1456.

Benson, D. A., Karsch-Mizrachi, I., Lipman, D. J., Ostell, J. \& Wheeler, D. L. (2006). GenBank. Nucleic Acids Res 34 (Database issue), D16D20.

Bisgaard, M. (1993). Ecology and significance of Pasteurellaceae in animals. Zentralbl Bakteriol 279, 7-26.

Bisgaard, M., Mutters, R. \& Mannheim, W. (1983). Characterization of some previously unreported taxa isolated from guinea pigs (Cavia porcellus) and provisionally classed with the "HPA-group". INSERM 114, 227-244.

Bisgaard, M., Houghton, S. B., Mutters, R. \& Stenzel, A. (1991). Reclassification of German, British and Dutch isolates of so-called Pasteurella multocida obtained from pneumonic calf lungs. Vet Microbiol 26, 115-124.

Bojesen, A. M., Larsen, J., Pedersen, A. G., Mörner, T., Mattson, R. \& Bisgaard, M. (2007). Identification of a novel Mannheimia granulomatis lineage from lesions in roe deer (Capreolus capreolus). J Wildl Dis 43, 345-352.

Boot, R. \& Bisgaard, M. (1995). Reclassification of 30 Pasteurellaceae strains isolated from rodents. Lab Anim 29, 314-319.

Boot, R. \& Walvoort, H. C. (1986). Otitis media in guinea pigs: pathology and bacteriology. Lab Anim 20, 242-248.

Boot, R., Oosterom, J. \& Walvoort, H. C. (1983). Recovery of members of the Pasteurella-Actinobacillus-group from guinea pigs. Lab Anim 17, 285-289.

Boot, R., Thuis, H., Bakker, R. H. G. \& Veenema, J. L. (1995). An enzyme-linked immunosorbent assay (ELISA) for monitoring antibodies to SP group Pasteurellaceae in guineapigs. Lab Anim 29, 59-65.

Cashion, P., Holder-Franklin, M. A., McCully, J. \& Franklin, M. (1977). A rapid method for the base ratio determination of bacterial DNA. Anal Biochem 81, 461-466.

Christensen, H. \& Bisgaard, M. (2008). Taxonomy and biodiversity of members of Pasteurellaceae. In Pasteurellaceae, Biology, Genomics and Molecular Aspects, pp. 1-26. Edited by P. Kuhnert \& H. Christensen. Norfolk: Caister Academic Press.

Christensen, H., Bisgaard, M., Angen, Ø. \& Olsen, J. E. (2002a). Final classification of Bisgaard taxon 9 as Actinobacillus arthritidis sp. nov. and recognition of a novel genomospecies for equine strains of Actinobacillus lignieresii. Int J Syst Evol Microbiol 52, 1239-1246. 
Christensen, H., Bisgaard, M. \& Olsen, J. E. (2002b). Reclassification of equine isolates previously reported as Actinobacillus equuli, variants of A. equuli, Actinobacillus suis or Bisgaard taxon 11 and proposal of A. equuli subsp. equuli subsp. nov. and A. equuli subsp. haemolyticus subsp. nov. Int J Syst Evol Microbiol 52, 1569-1576.

Christensen, H., Kuhnert, P., Bisgaard, M., Mutters, R., Dziva, F. \& Olsen, J. E. (2005). Emended description of porcine [Pasteurella] aerogenes, [Pasteurella] mairii and [Actinobacillus] rossii. Int J Syst Evol Microbiol 55, 209-223.

Christensen, H., Kuhnert, P., Busse, H.-J., Frederiksen, W. C. \& Bisgaard, M. (2007). Proposed minimal standards for the description of genera, species and subspecies of the Pasteurellaceae. Int J Syst Evol Microbiol 57, 166-178.

Christie, R., Atkins, N. E. \& Munch-Petersen, E. (1944). A note on a lytic phenomenon shown by group B streptococci. Aust J Exp Biol 22, 197-200.

De Ley, J., Cattoir, H. \& Reynaerts, A. (1970). The quantitative measurement of DNA hybridization from renaturation rates. Eur $J$ Biochem 12, 133-142.

Felsenstein, J. (1995). PHYLIP (Phylogeny Inference Package) version 3.5c. Seattle: Department of Genetics, University of Washington.

Frederiksen, W. (1973). Pasteurella taxonomy and nomenclature. In Yersinia, Pasteurella and Francisella, Contributions to Microbiology and Immunology, pp. 170-176. Vol. 2. Edited by S. Winblad. Basel: Karger.

Frederiksen, W. (1981). Gas producing species within Pasteurella and Actinobacillus. In Haemophilus, Pasteurella and Actinobacillus, pp. 185-196. Edited by M. Kilian, W. Frederiksen \& E. L. Biberstein. London: Academic Press.

Ganaway, J. R. (1976). Bacterial, mycoplasma and rickettsial diseases. In The Biology of the Guinea Pig, pp. 121-135. Edited by J. E. Wagner \& P. J. Manning. New York: Academic Press.

Huß, V. A. R., Festl, H. \& Schleifer, K. H. (1983). Studies on the spectrophotometric determination of DNA hybridization from renaturation rates. Syst Appl Microbiol 4, 184-192.

Korczak, B., Christensen, H., Emler, S., Frey, J. \& Kuhnert, P. (2004). Phylogeny of the family Pasteurellaceae based on $r p o B$ sequences. Int $J$ Syst Evol Microbiol 54, 1393-1399.

Kuhnert, P. \& Korczak, B. M. (2006). Prediction of whole-genome DNA-DNA similarity, determination of $\mathrm{G}+\mathrm{C}$ content and phylogenetic analysis within the family Pasteurellaceae by multilocus sequence analysis (MLSA). Microbiology 152, 2537-2548.

Kuhnert, P., Korczak, B. M., Christensen, H. \& Bisgaard, M. (2007). Emended description of Actinobacillus capsulatus Arseculeratne 1962, $38^{\mathrm{AL}}$. Int J Syst Evol Microbiol 57, 625-632.
Kunstýr, I. \& Hartmann, D. (1983). Pasteurella pneumotropica and the prevalence of the AHP (Actinobacillus, Haemophilus, Pasteurella)group in laboratory animals. Lab Anim 17, 156-160.

Mannheim, W. (1981). Taxonomic implications of DNA relatedness and quinone patterns in Actinobacillus, Haemophilus, and Pasteurella. In Haemophilus, Pasteurella and Actinobacillus, pp. 265-280. Edited by M. Kilian, W. Frederiksen \& E. L. Biberstein. London: Academic Press.

Mannheim, W., Pohl, S. \& Stenzel, W. (1978). [Unclassified pasteurella-like organisms isolated from guinea pigs (author's transl.)]. Zentralbl Bakteriol [Orig A] 241, 329-336.

Mollet, C., Drancourt, M. \& Raoult, D. (1997). $r p o B$ sequence analysis as a novel basis for bacterial identification. Mol Microbiol 26, 10051011.

Mráz, O., Sisák, F. \& Jelen, P. (1979). The pasteurella carriers in farm and laboratory animals. Comp Immunol Microbiol Infect Dis 2, 437445.

Mutters, R., Pohl, S. \& Mannheim, W. (1986). Transfer of Pasteurella ureae Jones 1962 to the genus Actinobacillus Brumpt 1910: Actinobacillus ureae comb. nov. Int J Syst Bacteriol 36, 343-344.

Mutters, R., Mannheim, W. \& Bisgaard, M. (1989). Taxonomy of the Group. In Pasteurella and Pasteurellosis, pp. 3-34. Edited by C. Adlam \& J. M. Rutter. London: Acad Press.

Olsen, G. J., Matsuda, H., Hagstrom, R. \& Overbeek, R. (1994). fastDNAmL: a tool for construction of phylogenetic trees of DNA sequences using maximum likelihood. Comput Appl Biosci 10, 41-48.

Rice, P., Longden, I. \& Bleasby, A. (2000). EmBoss: the European molecular biology open software suite. Trends Genet 16, 276-277.

Stewart, D. D. \& Letscher, R. M. (1976). Isolation of an atypical Pasteurella-like organism from guinea pig abscesses. Lab Anim Sci 26, 482-485.

Thompson, J. D., Gibson, T. J., Plewniak, F., Jeanmougin, F. \& Higgins, D. G. (1997). The CLUSTAL_X windows interface: flexible strategies for multiple sequence alignment aided by quality analysis tools. Nucleic Acids Res 25, 4876-4882.

Tindall, B. J., Rosselló-Móra, R., Busse, H.-J., Ludwig, W. \& Kämpfer, P. (2010). Notes on the characterization of prokaryote strains for taxonomic purposes. Int J Syst Evol Microbiol 60, 249-266.

Wayne, L. G., Brenner, D. J., Colwell, R. R., Grimont, P. A. D., Kandler, O., Krichevsky, M. I., Moore, L. H., Moore, W. E. C., Murray, R. G. E. \& other authors (1987). Report of the Ad Hoc committee on reconciliation of approaches to bacterial systematics. Int J Syst Bacteriol 37, 463-464.

Zeigler, D. R. (2003). Gene sequences useful for predicting relatedness of whole genomes in bacteria. Int J Syst Evol Microbiol 53, 1893-1900. 